Ks. Piotr SZCZUR*

\title{
PRZEBACZENIE GRZECHÓW W NAUCZANIU JANA CHRYZOSTOMA Zarys problematyki
}

Przebaczenie jest aktem nie dającym się wytłumaczyć w sposób racjonalny. Można je częściowo zrozumieć tylko wtedy, gdy spojrzy się na nie przez pryzmat miłości i miłosierdzia. Podobnie jest z przebaczeniem grzechów, które można zrozumieć w kontekście miłosierdzia Boga i Jego miłości do człowieka $\left(\varphi \imath \lambda \alpha \nu \theta \rho \omega \pi^{i} \alpha^{1}\right)$. Tzw. Credo Nicejsko-konstantynopolitańskie mówi o wierze $\mathrm{w}$, ,jeden chrzest na odpuszczenie grzechów"2. Wydawać się może, że stwierdzenie to wskazuje, iż tylko chrzest (paenitentia prima) jest środkiem uzyskania od Boga przebaczenia grzechów. Czy zatem jakość i sposób ludzkiego życia nie ma wpływu na uzyskanie od Boga przebaczenia? W tym kontekście istotne wydaje się podjęcie próby ukazania nauczania Jana Chryzostoma na temat przebaczenie, gdyż jako przedstawiciel ,szkoły antiocheńskiej” bardziej zwracał uwagę na praktyczny wymiar życia chrześcijańskiego.

1. Boża Opatrzność. Na początku Wielkiego Postu roku $387^{3} \mathrm{~W}$ Antiochii wybuchła rewolta podatkowa, która doprowadziła do zniszczenia

\footnotetext{
* Ks. dr hab. Piotr Szczur, prof. KUL - kierownik Katedry Historii Kościoła w Starożytności i Średniowieczu w Instytucie Historii Kościoła i Patrologii na Wydziale Teologii Katolickiego Uniwersytetu Lubelskiego Jana Pawła II; e-mail: p.szczur@kul.pl.

1 Termin $\varphi \imath \lambda \alpha v \theta \rho \omega \pi i \alpha$ przyjmuje następujące znaczenia: „ludzkość, życzliwość, ludzkie uczucia; stosunki wzajemne kochanków; pl. akty uprzejmości, grzeczności; miłość Boga do ludzi" (Abramowiczówna IV 515-516, s.v. $\varphi \imath \lambda \alpha \nu \theta \rho \omega \pi i \alpha)$. Podobne znaczenia podają również inne słowniki, por. Lampe, s. 1475-1476, s.v. $\varphi \imath \lambda \alpha \nu \theta \rho \omega \pi i \alpha$; Liddell - Scott, s. 1932, s.v. $\varphi \imath \lambda \alpha \nu \theta \rho \omega ́-$ $\pi \varepsilon v \mu \alpha(\varphi \imath \lambda \alpha \theta \rho \omega \pi i \alpha)$.

${ }^{2}$ Por. Concilium Constantinopolitanum I (381), Expositio fidei CL patrum, ŹMT 24 [wydanie grecko-łacińsko-polskie, układ i oprac. A. Baron - H. Pietras], tłum. T. Wnętrzak, Kraków 2002 $=$ DSP $1,68-69$.

${ }^{3}$ Szerzej na temat rewolty zob. R. Browning, The Riot of A.D. 387 in Antioch. The Role of the Theatrical Claques in the Later Empire, JRS 42 (1952) 13-20; J.H.W.G. Liebeschuetz, Antioch. City and Imperial Administration in the Later Roman Empire, Oxford 1972, 278-280; F. van de Paverd, St. John Chrysostom. The Homilies on the Statues, OCA 239, Roma 1991 (przedstawia streszczenie wydarzeń); D.R. French, Rhetoric and the Rebellion of A.D. 387 in Antioch, „Historia” 47(1998) 468-484; P. Filipczak, Bunty i niepokoje w miastach wczesnego Bizancjum (IV wiek n.e.), Łódź
} 
i sprofanowania posagów rodziny cesarskiej, przez co sprowadziła zagrożenie na miasto i obywateli. Reakcją Chryzostoma na zaistniałą sytuację było wygłoszenie jednej z najsłynniejszych serii homiliami $O$ posagach (Do ludu Antiocheńskiego) - De statuis (Ad populum Antiochaenum) ${ }^{4}$. Dla rozważań przedstawionych w niniejszym opracowaniu istotne jest, że homilie te zostały osadzone w kontekście wezwania do autentycznego przebaczenia. W Kościele starożytnym w czasie wielkiego postu odczytywano teksty zaczerpnięte z Księgi Rodzaju. Chryzostom zatem głosząc kazania wielkopostne wyjaśniał m.in. naukę Pisma Świętego na temat stworzenia świata. Przytaczając pierwszy werset Księgi Rodzaju: „Na początku Bóg stworzył niebo i ziemię” (Rdz $1,1)$ stara się ukazać przesłanie radości i nadziei, jakie zawarte jest w tej prawdzie. Podkreśla, że Bóg stworzył dla człowieka niebo, ziemię, morze, słońce, księżyc i wszystkie gwiazdy, i konkluduje, że jest to dowód miłości Boga. Ten fakt jest niezbitym dowodem na to, że wszechmocny Bóg stworzył tak wspaniały świat dla tak mizernej istoty jaką jest człowiek ${ }^{5}$. Niezwykłe jest to, że Bóg nie stworzył świata jako formy wynagrodzenia człowiekowi za jego pracę lub zasługi, lecz uczynił to z miłości do człowieka ${ }^{6}$. Chryzostom zręcznie przechodzi od zdumienia i podziwu nad dobrocią i hojnością Boga do wywołania u słuchaczy poczucia wdzięczności za dar stworzonych przez Boga rzeczy, które - jako stworzone przez Boga - są dobre (por. Rdz 1). Jednak zauważał, że nie wszyscy ludzie potrafią dostrzec, iż wszystko, co Bóg stworzył, jest dobre. Przypominał swym słuchaczom, że są tacy heretycy, którzy źle mówią o stworzonych przez Boga rzeczach, jak np. wino. Odnosząc się to tego zagadnienia pouczał:

„«Wino bowiem rozwesela serce człowieka» (Ps 103, 15), mówi Pismo [...]. To miejsce przydaje się nam także przeciw heretykom, którzy oskarżają wino, twór Boski. Gdyby bowiem należał do zakazanych, Paweł nie byłby na niego pozwolił, nie byłby powiedział, żeby wina używać. Jednak nie tylko przeciw heretykom się zwraca, lecz także przeciw naiwniejszym z naszych braci, którzy zobaczywszy jakichś ludzi zachowujących się nieprzyzwoicie wskutek pijaństwa, ich nie ganią, lecz oskarżają owoc dany przez Boga, mówiąc: «Niech nie będzie wina!» Powiedzmy im raczej: «Niech nie będzie pijaństwa!» Wino bowiem jest dziełem Boga, pijaństwo dziełem diabła. Nie wino stwarza pijaństwo, lecz niepowściagliwość stwarza pijaństwo. Nie oczerniaj

2009, 81-100; P. Szczur, Rewolta podatkowa w Antiochii (387) w świetle przekazów Jana Chryzostoma i Libaniusza. Retoryka i fakty historyczne, „Roczniki Historii Kościoła” 1(56) (2009) 49-75.

${ }^{4}$ Wydanie tekstu: J.P Migne, w: PG 49, 15-222; ed. M.L. Cervini: Discorso esortatorio per l'inizio della santa quaresima, Corona Patrum Salesiana. Sanctorum Patrum Graecorum et Latinorum Opera Selecta. Series Graeca 16, Torino 1953; thum. homilii 1. i 19. T. Sinko w: Św. Jan Złotousty, Dwadzieścia homilij i mów, Kraków 1947, 44-71 i 72-87.

${ }^{5}$ Por. Joannes Chrysostomus, Ad populum Antiochenum hom. 7, 2-3, PG 49, 93-95.

${ }^{6}$ Por. tamże 7, 2, PG 49, 93. 
tworu Boga, lecz oskarżaj o szaleństwo współniewolnika! Ale ty, zaniechawszy karcenia i poprawiania grzesznika, obrażasz dobroczyńcę"7 .

W wypowiedziach Jana Chryzostoma odnajduje się akceptację dobra stworzeń i radość ze stworzonego przez Boga świata. Co więcej, autor idzie nawet dalej, odwołując się do wskazania św. Pawła danego Tymoteuszowi: „używaj po trosze wina ze względu na żołądek i częste twe słabości” (1Tm 5, 23), pyta: „Dlaczego więc Bóg pozwolił, ażeby taki święty, który kierował się wielkimi sprawami, popadł w chorobę, i ani on sam ani jego nauczyciel nie potrafił go wyleczyć, lecz potrzebowali pomocy wina?"8 Ten obraz z kolei pozwala Złotoustemu Kaznodziei przedstawić obywatelom Antiochii opis Bożej Opatrzności ${ }^{9}$. Kaznodzieja doskonale zdawał sobie sprawę z różnego rodzaju wątpliwości, jakie rodziły się w tej kwestii w umysłach i sercach jego słuchaczy. Dlatego mówi:

„Słyszeliście przecież, że wielu takie zadawało pytanie: «Dlaczego taki a taki, człowiek umiarkowany i przyzwoity, każdego dnia bywa wleczony do sądu przez drugiego, który jest przestępcą i człowiekiem złym, i doznaje od niego tysiącznych przykrości, a Bóg na to pozwala? Dlaczego inny, fałszywie oskarżony, poniósł niesłuszną śmierć?» Tamten utonął w morzu, inny spadł w przepaść. I moglibyśmy wymienić wielu świętych z naszych czasów i z czasów naszych przodków, którzy doznali wielu urozmaiconych prześladowań"10.

Chryzostom jako doskonały obserwator życia codziennego i znawca ludzkiej natury, wiedział, że jego słuchaczom trudno było zrozumieć dlaczego Bóg pozwala, aby ludzie dobrzy i żyjący uczciwie byli krzywdzeni przez złych lub doświadczali różnego rodzaju nieszczęść. Dlatego odwołuje się do Opatrzności Bożej. Wydaje się, że rozumienie Opatrzności ma dla Chryzostoma kluczowe znaczenie dla właściwego zrozumienia przebaczenia. Bóg dopuszcza ${ }^{11}$, aby „święci” byli doświadczani i cierpieli zło, gdyż życie pozbawione dynamiki żalu za grzechy pozostaje „uwięzione” w grzechu. W tym kontekście Antiocheńczyk wymienia osiem przyczyn udręczeń świętych:

${ }^{7}$ Tamże 1, 4, PG 49, 22, tłum. Sinko, s. 52. Na temat krytyki pijaństwa zob. P. Szczur, John Chrysostom's Assessment of Drunkenness, VoxP 33 (2013) t. 59, 387-400.

${ }^{8}$ Joannes Chrysostomus, Ad populum Antiochenum hom. 1, 5, PG 49, 22-23, tłum. Sinko, s. 53: „«Wina potrosze używaj» $(1 \mathrm{Tm} 5,23)$; bo tylko na umiarkowane picie z powodu choroby pozwolił i gdyby ucznia nie była dręczyła choroba, nie byłby go zmuszał nawet do miernego używania".

${ }^{9}$ Szerzej na temat rozumienia Opatrzności przez Chryzostoma zob. G.D. Dragas, St. John Chrysostom's doctrine of God's providence, „Ekklesiastikos Pharos” 57 (1957) 375-406; D. Ciarlo, Sulla teoria e la prassi della "providentia Dei» in Giovanni Crisostomo, „Atti della Accademia Pontaniana N.S." 56 (2007) 87-93.

${ }^{10}$ Joannes Chrysostomus, Ad populum Antiochenum hom. 1, 5, PG 49, 23, thum. Sinko, s. 54.

${ }^{11}$ Tamże 1, 6, PG 49, 23, tłum. Sinko, s. 53. 
„Pierwsza tedy przyczyna jest ta, że Bóg pozwala ich dotknąć cierpieniem, żeby się szybko nie wzbijali w zarozumiałość z powodu wielkości zasług i cudów.

Druga, ażeby drudzy nie uważali ich za coś wyższego od ludzi i za bogów, a nie za ludzi.

Trzecia, ażeby przez chorych i uwięzionych okazała się moc Boga, zwycięska i wyższa nad wszystko i wzmacniająca głoszenie Ewangelii.

Czwarta, aby się bardziej ujawniła cierpliwość ich samych, jako że nie służą Bogu dla zapłaty, ale okazują tak wielką wdzięczność, że i po tak wielkich doświadczeniach widnieje ich nieosłabione przywiązanie do Niego.

Piąta, abyśmy myśleli mądrze o zmartwychwstaniu. Gdy bowiem zobaczysz męża sprawiedliwego i pełnego wszelkiej cnoty, który doznał tysiącznych cierpień i tak stąd odchodzi, musisz nawet mimo woli na wszelki sposób pomyśleć coś o przyszłym sądzie. Jeżeli bowiem ludzie nie pozwalają odejść bez zapłaty i nagrody tym, którzy dla nich ponosili trudy, to tym bardziej Bóg nie chciałby nigdy odprawić bez wieńca tych, co tak wielce się mozolili. Jeśliby zaś nie chciał pozbawić ich kiedyś zapłaty za ich trudy, to musi po tutejszym końcu istnieć jakiś czas, w którym otrzymają nagrody za trudy tu poniesione.

Szósta, ażeby wszyscy popadający w cierpienia mieli dostateczną pociechę i zachętę, patrząc na tamtych i pamiętając o cierpieniach, które ich spotkały.

Siódma, ażebyście wtedy, kiedy wzywam was do ich cnoty i mówię do każdego z was: , «naśladuj Pawła», «współzawodnicz z Piotrem», nie sądzili, że oni z powodu nadzwyczajnych czynów mieli inną naturę, i nie ociągali się $\mathrm{z}$ ich naśladowaniem.

Ósma przyczyna, żebyśmy wtedy, kiedy trzeba uznać kogoś za szczęśliwego lub nieszczęśliwego, nauczyli się, kogo trzeba uważać za szczęśliwego, a kogo za nędznego i utrapionego"12.

Zagadnienie to jest najwyraźniej skomplikowane dla słuchaczy Antiocheńczyka, dlatego Chryzostom objaśnia i ilustruje to, co ma na myśli. Tłumaczy, że jeśli uważamy Boga za dobrego tylko wówczas, gdy czyni nam dobro, a gdy nas karze uważamy Go za złego, to czynimy Go dobrym jedynie $\mathrm{w}$ połowie ${ }^{13}$. Bóg jednych napełnia strachem, dla innych jest miłosierny, ale sam nie staje się ,podzielony”"14. Jako przykład Złotousty Kaznodzieja przywołuje postawę ojca i wyjaśnia, że swoje dzieci, które przecież kocha, niekiedy każe, ale nie z powodu swego okrucieństwa, lecz z troski o nie, a kary, które stosuje mają charakter wychowawczy. Skoro ojciec może karać swe dzieci z troski o nie, to o ile bardziej stosowne jest, aby tak właśnie myśleć o Bogu,

\footnotetext{
${ }^{12}$ Tamże, thum. Sinko, s. 54-55.

${ }^{13}$ Por. tamże 7, 2, PG 49, 94.

${ }^{14}$ Por. tenże, De paenitentia hom. 7, 3, PG 49, 327.
} 
który przecież jest najlepszym Ojcem dla każdego człowieka ${ }^{15}$. Chryzostom nie poprzestaje na jednym przykładzie, lecz przytacza kolejny odwołując się do postawy lekarza ${ }^{16}$. Tak jak lekarz nie jest tylko lekarzem, kiedy przemywa rany i karmi swojego pacjenta, ale także wtedy, kiedy przypala jego rany, tak samo Bóg - zarówno wtedy, gdy przebacza, jak i wtedy, gdy karze - jest wciąż tym samym Bogiem. Chryzostom włącza opis uzdrowicielskich działań Boga w szersze rozumienie Boskiej ekonomii. W Homiliach o pokucie, zachęcając do ujrzenia ostatecznego celu, do którego prowadzi Bóg $\left(\sigma \kappa \circ \pi_{\text {ó }}\right)^{17}$, wyjaśnia, jak Bóg rozciaga swoją ekonomię (oikovorí $\alpha)^{18}$ na cały świat. Ma to bezpośredni wpływ na ludzkie zachowanie: w świetle Bożej ekonomii mamy się nauczyć „metody” ratowania się z niebezpieczeństw, w które popadliśmy ( $\tau$ òv $\tau \rho o ́ \pi$ ov $\tau \hat{\eta} \varsigma ~ \alpha ̉ \pi \alpha \lambda \lambda \alpha \gamma \hat{\eta} \varsigma)^{19}$; każdy ma ,zadbać o swoją duszę i za cel obrać podążanie za ekonomią przyszłego życia" ${ }^{20}$.

2. Bóg Wspomożycielem. Chryzostom zauważa, że człowiek w zmaganiach $\mathrm{z}$ grzechem nie jest pozostawiony samemu sobie, co z kolei pozwala mu ukazać pełny zasięg Bożej ekonomii. Antiocheńczyk jest przekonany, że Bóg jest osobiście zaangażowany w życie każdego człowieka. Przedstawiając tę myśl Złotousty Kaznodzieja odwołuje się do wydarzeń mających miejsce po - wspominanej już - rewolcie podatkowej. W mieście sparaliżowanym strachem po znieważeniu i zbezczeszczeniu posagów cesarza i członków rodziny cesarskiej, Flawian, biskup Antiochii, udał się do Konstantynopola, aby błagać cesarza Teodozjusza o przebaczenie dla miasta. W 3. homilii Ad populum Antiochenum Chryzostom zapewniał słuchaczy, że kiedy cesarz jest błagany, a biskup jest tym, który błaga, to sam Bóg zadziała ${ }^{21}$,zmiękczając” serce cesarza. Chcąc ukazać tę prawdę Antiocheńczyk odwołuje się do opowiadania o królowej Esterze, która przyszła do króla Kserksesa, aby wstawić się za Izraelitami, którym groziła zagłada (por. Est 5). Podkreśla, że kiedy Estera stawiła się przed obliczem perskiego króla, aby błagać w imieniu Żydów, sam Bóg poszedł z nią:

„Jeśli kobieta błagająca za Żydów mogła uspokoić gniew barbarzyńcy, to tym bardziej nasz nauczyciel [tj. biskup Flawian], błagając w imieniu tak

${ }^{15}$ Por. tenże, Ad populum Antiochenum hom. 7, 3, PG 49, 94. Przy czym Chryzostom posługuje się obrazem ojca przede wszystkim dla zobrazowania kary pochodzącej od Boga.

${ }^{16}$ Chryzostom często wykorzystuje metaforę Boga jako ojca, lekarza czy nauczyciela. Metafory te są niezwykle istotne ze względów duszpasterskich.

${ }^{17}$ Por. Joannes Chrysostomus, De paenitentia hom. 7, 1, PG 49, 323.

${ }^{18}$ Por. tamże 7, 3, PG 49, 328; tamże 7, 4, PG 49, -329.

${ }^{19}$ Por. tamże 4, 2, PG 49, 301.

${ }^{20}$ Por. tamże 4, 3, PG 49, 303, thum. własne.

${ }^{21}$ Por. tenże, Ad populum Antiochenum hom. 3, 2, PG 49, 49. 
[znakomitego] miasta w połączeniu z tak [znakomitym] Kościołem, będzie w stanie przekonać tego najłagodniejszego i najmiłosierniejszego cesarza"22.

Natomiast w homilii 16. na List do Hebrajczyków (na tekst Hbr 9, 15-17) przypomina słuchaczom, że „mamy Boga, współpracującego [z nami] i pomagającego nam"23. Przekonanie to jest wprost wyrażone w Homilii o paralityku opuszczanym przez dach (por. Mk 2, 1-12; Łk 5, 17-26):

,jedną z korzyści było to, że jego dusza została oczyszczona przez długie cierpienie [...], ale była jeszcze nie mniejsza korzyść, że [Bóg] był przy nim obecny podczas jego próby [...]. To On go wzmocnił i podtrzymał, i wyciągnął ku niemu swoją dłoń, i pomógł mu, aby nie upadł. Ale kiedy słyszycie, że był to sam [Bóg], nie pozbawiajcie paralityka należnej mu pochwały [...]. Albowiem nawet, jeśli bylibyśmy nieskończenie mądrzy [...], bez Jego łaski nie bylibyśmy w stanie ustrzec się nawet przed najzwyklejszą pokusą"24.

Chryzostom ukazywał tę bliskość Boga w bardzo obrazowy sposób. Przykładowo, komentując fragment jednego z wersetów Księgi Jeremiasza (31, 32: „kiedy ująłem ich za rękę, by wyprowadzić z ziemi egipskiej”), pyta:

„Dlaczego Bóg wspomina o sposobie ( $\tau \rho o ́ \pi \circ \varsigma)$ wyjścia? [...] Po to, aby uka-

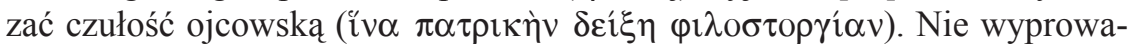
dził ich jak niewolników, lecz jak ojciec prowadzący dzieci”25.

Tak rozumiana przez Chryzostoma pełna miłości bliskość Boga była elementem pozwalającym kaznodziei na nieustanne zachęcanie słuchaczy do tego, aby żałując za grzechy nie byli zawstydzeni z powodu ich popełnienia, lecz dumni z tego, iż potrafią powrócić do miłującego ich Ojca. Bóg jest hojny w wybaczeniu i chce zbawienia ludzi. Jest tak blisko człowieka, że relacja między Nim a człowiekiem staje się na swój sposób intymna. Znamienne jest - co podkreśla Chryzostom - że miłosierdzie i przebaczenie zdecydowanie góruje nad szafowaniem wyrokami, że Bóg nawet „nie pamięta” o przewinach człowieka. W jednej z homilii O pokucie Chryzostom kończy swe rozważania nawiązaniem do przypowieści o synu marnotrawnym (por. Łk 15, 11-32). Kiedy marnotrawny syn powrócił,

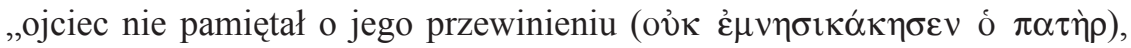
lecz przyjął go z otwartymi ramionami. Dlaczegóż to? Bo był ojcem, nie sędzią ("O

Mówi dalej:

\footnotetext{
${ }^{22}$ Tamże, PG 49, 50, tłum. własne.

${ }^{23}$ Tenże, In epistulam ad Haebraeos hom. 16, 4, PG 63, 128, thum. własne.

${ }^{24}$ Tenże, In paralyticum demissum per tectum 2, PG 51, 51, tłum. własne.

${ }^{25}$ Por. tenże, De paenitentia hom. 6, 4, PG 49, 320, thum. własne.

${ }^{26}$ Tamże 1, 4, PG 49, 283, thum Sinko, w: Dwadzieścia homilij i mów, s. 135.
} 
„Gdy trzeba ratować zagubionego - mówi - to nie czas na sądy, ani na dokładne śledztwo, ale tylko na ludzkość ( $\varphi \imath \lambda \alpha \nu \theta \rho \omega \pi i \alpha \varsigma)$ i przebaczenie $(\sigma v \gamma \gamma v \omega ́ \mu \eta \varsigma)^{\prime 27}$.

I w tym miejscu Chryzostom odwołuje się też do analogii medycznej:

„Żaden lekarz nie porzuca podawania choremu lekarstw i nie pociąga go potem do odpowiedzialności za nieporządne życie i nie karze"28.

Chryzostom zastanawia się następnie nad dobrze wychowanym, ale zgorszonym starszym bratem z tejże przypowieści, który najwyraźniej ma reprezentować lepiej wychowanych mieszkańców Antiochii, wahających się przed ponownym przyjęciem do wspólnoty kościelnej cudzołożników lub bywalców teatru. Przypomina im, że tak jak w działaniu Boga jest pełna miłości zażyłość, tak i musi być ona obecna w ich własnych czynach. Wyjaśnia: ojciec z przypowieści powiedział:

„Brata widzisz, nie obcego. Do ojca wrócił, a ten nie potrafił wcale pamiętać o przeszłości, a raczej pamięta tylko o tym, co by go mogło doprowadzić do współczucia, litości, miłości i pobłażliwości przystojnej rodzicowi"29.

W tej samej homilii Chryzostom nawiązuje też do przypowieści o zagubionej owcy (por. Łk 15, 3-7; Mt 18, 13-14) i podkreśla, że pasterz nie bił jej kiedy ją znalazł, lecz wziął na ramiona i przyniósł do owczarni ${ }^{30}$.

3. Bóg Odkupicielem. Takie rozumienie miłosiernego działania Chrystusa umożliwia Antiocheńczykowi wytłumaczenie dzieła zbawienia, którego On dokonał. W chrystologii Jana Chryzostoma można wskazać dwa aspekty nauczania o działalności i śmierci Chrystusa. Pierwszy wyraża się w akcentowaniu śmierci Chrystusa, która ma moc zbawczą:

„Przewiniliśmy i powinniśmy umrzeć; [Chrystus] umarł za nas i uczynił nas godnymi dziedzictwa [...], nigdy nie bylibyśmy zbawieni, gdyby nasz Pan nie umarł za nas"31.

Chryzostom opisuje dalej śmierć Chrystusa jako „okup”, który zniweczył tyranię śmierci. Tyrania istnieje wtedy, gdy ten, kto umarł nie może powrócić do życia ${ }^{32}$. Dalej mówi, że ofiary składane przez Żydów w czasach Starego

${ }^{27}$ Tamże.

${ }^{28}$ Tamże.

${ }^{29}$ Tamże, PG 49, 283-284, tłum Sinko, s. 135-136.

${ }^{30}$ Por. tamże, PG 49, 284, tłum Sinko, s. 136: „Z taką gorliwością, a raczej z większą, szukał zaginionej owcy. Tu bowiem syn sam powrócił, a tam odszedł sam pasterz i znalazłszy owieczkę, przyprowadził ją i cieszył się nią bardziej, niż wszystkimi, które był zachował. Patrz także jak ją przyprowadził! Nie bił jej batem, lecz wziął na ramiona, niósł i znowu oddał owczarni”.

${ }^{31}$ Tenże, In epistulam ad Haebraeos hom. 16, 1, PG 63, 123-124, tłum. własne.

${ }^{32}$ Por. tamże 17, 2, PG 63, 129. 
Testamentu (czyli przed Chrystusem) prowadziły do oskarżeń, a nie do uwolnienia od grzechu ${ }^{33}$. Były jedynie typami ( $\left.\alpha v \tau i \tau v \pi \alpha\right)$ wskazującymi na figurę, lecz same $\mathrm{w}$ sobie nie posiadały mocy przebłagania i pojednania z Bogiem. W 11. homilii na List do Rzymian Złotousty Kaznodzieja mówi:

„Nie leżało w mocy ludzkiej, powiada [Paweł], uwolnić nas od tego wszystkiego, lecz dzięki się należą Bogu, który chciał i mógł zdziałać tak wielkie rzeczy"34.

Drugi natomiast przejawia się w podkreślaniu prawdy o tym, że Chrystus jest zarówno prawdziwym Bogiem, jak i prawdziwym bratem człowieka:

„[Ten], który jest tak wielki, który jest odblaskiem chwały, który jest w postaci boskiej substancji, który stworzył światy, który siedzi po prawicy Ojca, nawet On chciał i pragnął stać się naszym bratem we wszystkim i z tego powodu opuścił aniołów i potęgi w niebie i zstapił do nas i przyjął naszą [naturę]. Rozważ zatem niezliczone dobrodziejstwa, [które On nam] wyświadczył: pokonał śmierć, uwolnił nas od tyranii diabła, wyzwolił z niewoli, uhonorował stając się [naszym] bratem: nie tylko zaszczycił braterstwem, lecz także niezliczonymi innymi [dobrodziejstwami]. Zechciał [także] stać się naszym Arcykapłanem przed Ojcem" ${ }^{\text {"35. }}$.

Takie przedstawienie Chrystusa, który był „naszym bratem we wszystkim”, wskazuje, jak ważne było dla Chryzostoma braterstwo. W 1. homilii $O$ posqgach, Chryzostom zachęca słuchaczy do naśladowania świętych postaci Starego Testamentu. Twierdził, że dążenie do cnót, które oni posiadali jest możliwe, gdyż byli oni takimi samymi ludźmi jak posiadającymi taką samą naturę:

„[...] żeby nie mówić, że wezwano nas do tej samej cnoty, co tamtych, którzy mieli inną naturę, albo nie byli ludźmi. Dlatego ktoś o wielkim Eliaszu, powiada: «Eliasz był człowiekiem podległym podobnym słabościom, jak my» (Jk 5, 17). Czy widzisz, że na podstawie wspólnych słabości ogłasza go za człowieka na naszą miarę? I znowu: «Albowiem ja jestem człowiekiem w cierpieniach do was podobnym» (Mdr 7, 1; por. 1Kor 4, 11). To też gwarantuje wspólność natury" ${ }^{\text {36. }}$.

Tak samo jest też i z Chrystusem, który był - co podkreśla Chryzostom - „naszym bratem we wszystkim", jednak wskazując na tę prawdę Złotousty Kaznodzieja - chociaż jest przedstawicielem szkoły antiocheńskiej - dystansuje się od adopcajanizmu:

${ }^{33}$ Por. tamże 17, 3, PG 63, 130.

${ }^{34}$ Tenże, In epistulam ad Romanos hom. 11, 4, PG 60, 489, thum. T. Sinko: Św. Jan Chryzostom, Homilie na List św. Pawła do Rzymian, oprac. A. Baron, t. 1, Kraków 1995, 168.

${ }^{35}$ Tenże, In epistulam ad Haebraeos hom. 5, 1, PG 63, 47, thum. własne.

${ }^{36}$ Tenże, Ad populum Antiochenum hom. 1, 9, PG 49, 28, thum. Sinko, s. 62. 
„[On] jest miłosierny, nie ustanawiając dla nas Najwyższego Kapłana, lecz sam stał się Najwyższym Kapłanem dla wierzących"37.

Tak więc Chryzostom akcentuje w osobie Chrystusa pewną łączność tego, co wieczne i duchowe z tym, co doczesne i materialne; Chrystus jest jednocześnie Kapłanem i Ofiarą ${ }^{38}$, jest prawdziwym Bogiem i prawdziwym człowiekiem, który zna ludzkie słabości i wie, co ludzka natura musi wycierpieć.

4. Kościól przestrzenią miłosiernej działalności Boga. W wypowiedziach Antiocheńczyka na temat chrztu, który jest „bramą” przez którą wchodzi się do Kościoła, pojawia się kilka wątków. Po pierwsze, warto zauważyć, że dla Chryzostoma chrzest jest bardziej ,zanurzeniem” w śmierci niż w życiu Chrystusa, które przeżył On dla dobra człowieka. Złotousty Kaznodzieja mówi:

„,chrzest jest krzyżem. Czym więc dla Chrystusa jest krzyż i grób, tym dla nas stał się chrzest, chociaż nie w tym samym znaczeniu. On bowiem umarł w ciele został pogrzebany, my zaś [doznajemy] jednego i drugiego przez grzech"39.

Narzędziem jest Chrystus. On ,zgładził i pogrzebał dawne grzechy"40. I tak jak On powstał z martwych w swoim ciele, tak i ludzie podniosą się ze swych grzechów.

„A jak dokonuje się takie zmartwychwstanie? Skoro grzech zostaje uśmiercony, a sprawiedliwość zmartwychwstaje, wówczas stare życie znika, a nowe jest prowadzone. Gdy zaś usłyszysz o nowym życiu, doszukuj się wielkiej przemiany i głębokiego przebaczenia"41.

Po drugie, Złotousty Kaznodzieja zauważa, że wprawdzie Chrystus pokonał grzech, ale przecież ludzie upadają i grzeszą. Dlatego Chryzostom niepokoi się o wiernych, którzy - potencjalnie - mogą popełniać grzechy po chrzcie. $Z$ tego względu nieustannie przypomina ludowi powierzonemu jego trosce, że chociaż chrzest sprawił, że umarliśmy dla grzechu, to jednak musimy ten stan utrzymywać dzięki własnym wysiłkom:

„To bowiem raz zdziałał chrzest: uczynił nas martwymi dla grzechu. Odtąd trzeba ten stan nieustannie podtrzymywać naszym usilnym staraniem ( $\pi \alpha \rho \grave{\alpha}$

${ }^{37}$ Tenże, In epistulam ad Haebraeos hom. 5, 1, PG 63, 47, tłum. własne. Dla Chryzostoma była to ważna kwestia, por. tamże 15, 2, PG 63, 119, thum. własne: „Nie przyszedł najpierw, aby potem stać się [Najwyższym Kapłanem], ale przyszedł i stał się [nim] w tym samym czasie".

${ }^{38}$ Por. tamże 17, 1, PG 63, 129.

${ }^{39}$ Tenże, In epistulam ad Romanos hom. 10, 4, PG 60, 480, tłum. Sinko, t. 1, s. 155. Por. tamże 11, 1, PG 60, 484, thum. Sinko, t. 1, s. 162: „Ponieważ zostaliśmy pogrzebani w wodzie, a On w ziemi, my ze względu na grzech, a On ze względu na ciało".

${ }^{40}$ Tamże 11, 5, PG 60, 490, thum. Sinko, t. 1, s. 170.

${ }^{41}$ Tamże 10, 4, PG 60, 480, tłum. Sinko, t. 1, s. 156. 
$\tau \hat{\tau} \varsigma \dot{\eta} \mu \varepsilon \tau \varepsilon \dot{\varepsilon} \rho \varsigma \varsigma$ $\sigma \pi 0 v \delta \hat{\eta} \varsigma)$, ażeby pomimo rzucanych przezeń tysięcznych wezwań, więcej go nie słuchać, lecz pozostać niewzruszonym jak trup" ${ }^{\text {"42. }}$.

Nie ma drugiej ofiary za grzechy, jeśli grzeszymy z własnej woli ${ }^{43}$; może być skrucha, ale nie ma drugiego krzyża ${ }^{44}$; jeśli Chrystus nie umiera powtórnie, to nie ma też drugiego obmycia ${ }^{45}$ :

„Jeśli bowiem przed chrztem grzech spowodował śmierć cielesną i rana potrzebowała tak poważnego leczenia, że Pan wszechrzeczy zstąpił na śmierć i w ten sposób zniszczył zło, czegóż nie spowoduje grzech po tak wielkim darze - po przywróceniu wolności, znowu czepiając się tego, który dobrowolnie się poddaje?"46.

Po trzecie, Chryzostom dostrzega, że żal za grzechy nie jest w całości dziełem człowieka. Antiocheńczyk w jednej z homilii $O$ pokucie twierdzi, że to Bóg daje łaskę skruchy: „bracia, przyjmijmy od Boga żal za grzechy ( $\tau \grave{\eta} v$

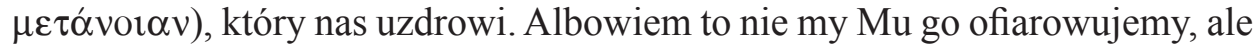
to On nam go dał" "47. W następnej zaś homilii zauważa, że w zasadzie skrucha jest możliwa tylko dzięki Bożemu miłosierdziu, które jest nieskończone:

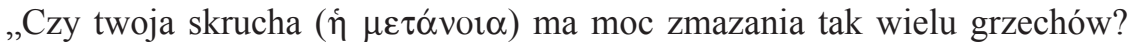

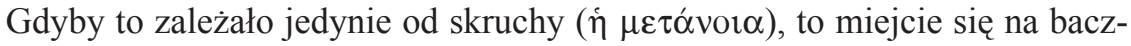
ności, ale skoro skrucha ( $\tau \hat{n} \mu \varepsilon \tau \alpha v o i ́ \alpha$ ) łączy się z miłosierdziem Boga

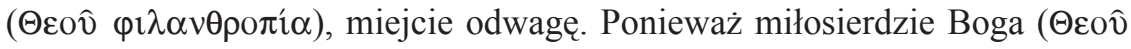
$\varphi \imath \lambda \alpha \nu \theta \rho o \pi i \alpha)$ jest niezmierzone [...]. Czym jest jedna iskra w porównaniu

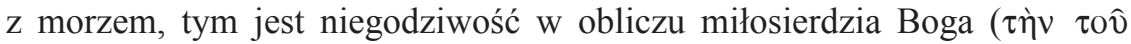

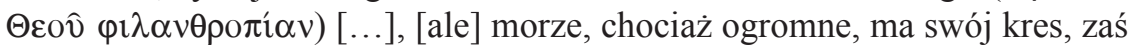
Boże miłosierdzie ( $\tau$ ov $\Theta \varepsilon \circ \hat{v} \varphi \imath \imath \alpha \nu \theta \rho o \pi i ́ \alpha$ ) jest nieskończone" ${ }^{48}$.

Chryzostom podkreśla, że łaskę Bożego miłosierdzia można odnaleźć w Kościele. Dlatego ci, których życie zostało naznaczone grzechem, w nim powinni szukać pomocy, gdyż Kościół jest miejscem odnowy i przemiany życia:

„Jakaż przystań ${ }^{49}$ jest lepsza niż Kościół? [...] Kiedy znajdę cierń, zmieniam go w gałązkę oliwną, ponieważ [rzeczy] tutaj nie są skażone ubóstwem

${ }^{42}$ Tamże, PG 60, 479, thum. Sinko, t. 1, s. 155.

${ }^{43}$ Por. tenże, In epistulam ad Hebraeos hom. 20, 1, PG 63, 143.

${ }^{44}$ Por. tamże.

${ }^{45}$ Por. tenże, In epistulam ad Romanos hom. 11, 2, PG 60, 485, tłum. Sinko, t. 1, s. 163: „Jeśli bowiem [Chrystus] drugi raz nie umiera, to nie ma drugiej kapieli chrztu; a jeśli nie ma drugiej kąpieli chrztu, to strzeż się, byś i ty nie był skłonny do grzechu!"

${ }^{46}$ Tamże 11, 4, PG 60, 488, thum. Sinko, t. 1, s. 167.

${ }^{47}$ Tenże, De paenitentia hom. 7, 3, PG 49, 327, tłum. własne.

${ }^{48}$ Tamże 8, 1, PG 49, 337, tłum. własne.

49 Przedstawienie Kościoła jako portu/przystani jest dość powszechne u Chryzostoma, zob. tamże 2, 1, PG 49, 285, gdzie Kościół jest przystanią zarówno dla grzeszników, jak i dla prawych. 
natury, lecz są zaszczycone wolnością wyboru. Jeśli znajduję wilka, przemieniam go w owieczkę nie zmieniając natury, ale przemieniając sposób życia"50.

Kościół - mówi dalej Chryzostom - jest lepszy od Arki Noego, ponieważ udoskonala tych, których przyjmuje na swe łono:

„Arka zabrała zwierzęta i trzymała je jako zwierzęta, Kościół zaś przyjmuje zwierzęta lecz przemienia [je]. Rozważ, co mówię: [do Arki] to, co wchodziło, to [samo] wychodziło: wchodził wilk i wychodził wilk; [...] do [Kościoła] zaś wchodzi wilk, a wychodzi owieczka, wchodzi wąż, a wychodzi baranek, nie dlatego, że zmienia się natura, lecz [dlatego, że] zostaje wypędzona niegodziwość" 51 .

Wizja Kościoła jako miejsca praktykowania skruchy i uzyskania przebaczenia grzechów jest dla Chryzostoma bardzo ważna. Dlatego w niektórych wypowiedziach bardzo ostro występuje przeciw tym, którzy Kościoła nie traktują poważnie oraz przeciw temu, co dzieje się w kościołach. W jednej homilii z serii Ad populum Antiochenum Chryzostom protestuje przeciw traktowaniu obecności w kościele jako rozrywki. Głoszone w kościele słowo powinno być przyjmowane z największą powagą i wcielane w życie, aby przemieniało je i doskonaliło. Nie dziwi więc, że Chryzostom odnoszą się to tego upomina wiernych: „Kościół to nie teatr i nie powinniśmy słuchać dla rozrywki" 52 . W innej zaś homilii dość obszernie wypowiada się na temat niestosowności śmiechu w kościele ${ }^{53}$.

Dla Chryzostoma zatem zadanie Kościoła polegające na zachęcaniu do odmieniania drogi życia i trwania na tej drodze było przedmiotem głębokiej troski, ponieważ praktykowanie życia prawdziwie chrześcijańskiego powinno prowadzić do przemiany postępowania i unikania grzechów. Złotousty zauważa, że Boga bardziej raduje czystość ludzkich serc, a nie ilość przyjętych Komunii ${ }^{54}$.

Chryzostom ubolewa nad tym, że człowiek jest istotą gnuśną, nie chce trwać w stanie łaski uświęcającej i bardzo łatwo powraca do grzesznego życia. Przyobleczony w sakramencie chrztu ,nowy człowiek”, poprzez popełnianie grzechów, szybko się starzeje. Antiocheńczyk zauważa, że „,po odmłodzeniu zgotowanym przez łaskę [tj. po chrzcie] sprowadzamy na siebie starość,

Chryzostom posiada bardzo szerokie rozumienie Kościoła. W De paenitentia hom. 3, 4, PG 49, 297 , prezentując swą wizję, mówi: „Kościół jest szpitalem, a nie salą sądową”, tłum. własne.

${ }^{50}$ Tamże 8, 1, PG 49, 335-336, thum. własne

${ }^{51}$ Tamże, PG 49, 336-337, tłum. własne

${ }^{52}$ Tenże, Ad populum Antiochenum hom. 2, 4, PG 49, 38, tłum. własne.

${ }^{53}$ Por. tenże, In epistulam ad Hebraeos hom. 15, 3-4, PG 63, 121-122. Warto zaznaczyć, że Chryzostom ma też wiele zastrzeżeń co do gorliwości religijnej Antiocheńczyków, którym wytyka m.in. słabą frekwencję na Mszach św., wychodzenie z kościoła i niegodne przystępowanie do Komunii; por. P. Szczur, Problematyka społeczna w późnoantycznej Antiochii na podstawie nauczania homiletycznego Jana Chryzostoma, Lublin 2008, 73-79.

${ }^{54}$ Por. Joannes Chrysostomus, In epistulam ad Hebraeos hom. 17, 4, PG 63, 132. 
pochodzącą z grzechów"55. Przedstawiając tę prawdę słuchaczom Złotousty Kaznodzieja posługuje się wymownym obrazem obrzydliwego starca ${ }^{56}$ :

„Nie można bowiem, nie można ujrzeć ciała tak zniszczonego przez starość, jak zrujnowana jest dusza upadająca na skutek grzechów. Popada ona już w ostateczne błazeństwo, bełkoce niewyraźnie jak starcy i obłąkani, cała sparaliżowana, ogłupiała, bez pamięci, z zaropiałymi oczyma, staje się wstrętna dla ludzi, a łatwa do zdobycia dla diabła. Takie to są dusze grzeszników. [...] Dusze grzeszników, gdy napotkają drobną przeszkodę, natychmiast upadają i ulegają zatraceniu. [...] ludzie żyjący w grzechach są chwiejni i wystawieni na napaści ze strony wszystkich. Nie widzą oni jasno, nie słyszą wyraźnie, nie mówią zrozumiale, lecz dławią się czkawką, a z ust toczą ciekącą ślinę. I oby tylko ślinę! To nie byłoby zupełnie nie do zniesienia. Teraz jednak miotają słowa bardziej cuchnące niż błoto i co gorsza, nie potrafią nawet wypluć śliny tych słów, lecz zgarniają do ręki w odrażający sposób i znowu ją rozcierają, gdy jest gęsta i nie do starcia"57.

Pomimo tego, iż grzech prowadzi do ,zestarzenia się duszy”, to jednak człowiek - jeśli tylko zechce - przez podjęcie decyzji o przemianie życia może się odmłodzić duchowo. Potwierdzają swoje stanowisko Antiocheńczyk odwołuje się do przypowieści o synu marnotrawnym (por. Łk 15, 11-32), który doznawszy nędzy i upokorzenia stał się jak opisywany wyżej starzec, jednak

„skoro zechciał, stał się nagle młodym pod wpływem jednego aktu woli i przemiany. Gdy sobie powiedział «Wrócę do ojca mego» (Łk 15, 18), te słowa przysporzyły mu wszelkiego dobra, a raczej nie tylko słowa, lecz i czyn dodany do słów. Rzekłszy bowiem: «Wrócę», nie pozostał w miejscu, lecz powiedział: «Wrócę», i wrócił odbywszy całą tę powrotną drogę"58.

Warto zwrócić uwagę, że Chryzostom mówiąc o „powrocie” do Ojca nie ogranicza tego aktu tylko do kwestii woli, lecz podkreśla, że za wolą musi iść czyn - konkretna postawa wyrażająca rzeczywistą realizację powziętej decyzji. Nie dziwi więc, że Antiocheńczyk w głoszonych kazaniach nieustannie przypomina o tym, że deklaracjom i woli muszą towarzyszyć faktyczne czyny ukazujące deklarowaną zmianę: „Czy nasze [nauki] są bajkami? Jeśli jesteście chrześcijanami, wierzcie w Chrystusa: jeśli wierzycie w Chrystusa, to pokażcie mi [swoja] wiarę przez czyny"59.

${ }^{55}$ Tenże, In epistulam ad Romanos hom. 10, 5, PG 60, 481, tłum. Sinko, t. 1, s. 156.

${ }^{56}$ Jan Chryzostom bardzo pozytywnie wypowiada się na temat ludzi starych i powierza im ważne funkcje wychowawcze, jednak dostrzega też ich wady, przez które deprecjonują starość; por. P. Szczur, Wady ludzi starych w ocenie Jana Chryzostoma, VoxP 31 (2011) t. 56, 371-382.

${ }^{57}$ Joannes Chrysostomus, In epistulam ad Romanos hom. 10, 5, PG 60, 481, thum. Sinko, t. 1, s. $156-157$.

${ }^{58}$ Tamże.

${ }^{59}$ Tenże, Ad populum Antiochenum hom. 5, 2, PG 49, 71, tłum. własne. 
Chryzostom naucza, że nie byłoby prawdą, gdybyśmy powiedzieli, że cały ciężar odpowiedzialności spada na jednostkę ludzką. Człowiek otrzymuje od Boga dwa dary: „uwolnienie od grzechu i wzięcie w niewolę sprawiedliwości”60 - i to, jak mówi Chryzostom, ,jest lepsze od wszelkiej wolności”61. Wyjaśniając tę prawdę odwołuje się do przykładu osieroconego chłopca, który został wzięty do niewoli, a następnie wyzwolony i adoptowany przez jakiegoś obywatela ${ }^{62}$. Podkreśla, że Bóg dokładnie to samo zrobił z człowiekiem. Nie tylko uwolnił go od grzechu, ale poprowadził do ,anielskiego życia” i zgładził poprzednie grzechy oraz uśmiercił starego człowieka ${ }^{63}$. Przed nadejściem Chrystusa:

„ciało nasze [...] było łatwą zdobyczą dla grzechu, gdyż po nastaniu śmierci wtargnął do niego wielki rój namiętności; dlatego też nie było zbyt skromne do ubiegania się o cnotę. Ani nie było pomocy Ducha, ani chrztu zdolnego uśmiercić [grzech]" ${ }^{\prime 64}$.

Bóg nie tylko zesłał Ducha Świętego ku pomocy ludziom, nie tylko ustanowił sakrament chrztu gładzący ludzkie grzechy, lecz także „nadobficie” udzielił człowiekowi łaski, która:

„nie tylko uwolniła od kary, lecz także udzieliła odpuszczenia grzechów, dała życie i inne dobra, o których nieraz mówiliśmy. To było tak, jakby ktoś kogoś gorączkującego nie tylko uwolnił od choroby, ale też uczynił urodziwym, silnym i czczonym; albo znów, gdyby głodnego nie tylko nakarmił, ale też uczynił panem wielu bogactw i wyniósł na najwyższy urząd" ${ }^{65}$.

Poczucie wszechogarniającej hojności przedstawione powyżej ma podstawowe znaczenie dla Chryzostomowej nauki o przebaczeniu. W Bogu istnieje niezwykła i niewytłumaczalna hojność. W tej samej homilii Chryzostom mówi

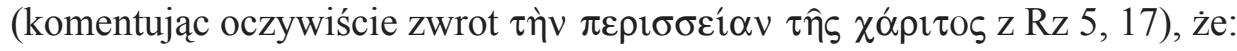

„otrzymaliśmy nie tylko lekarstwo odpowiadające ranie, lecz także zdrowie, piękność, cześć, chwałę i godności o wiele przewyższające naszą naturę. [...]. Znacznie więcej niż byliśmy winni, zapłacił za nas Chrystus, o tyle więcej, o ile większe jest niezmierzone morze w porównaniu z małą kroplą" ${ }^{\prime \prime}$.

${ }^{60}$ Tenże, In epistulam ad Romanos hom. 11, 4, PG 60, 489, thum. Sinko, t. 1, s. 168.

${ }^{61}$ Tamże.

${ }^{62}$ Tamże: „Bóg zrobił tak samo, jak gdyby ktoś, wziąwszy do barbarzyńców osieroconego chłopca, uprowadzonego do ich kraju, nie tylko uwolnił go od niewoli, lecz także ustanowił się jego ojcem i opiekunem i wyniósł go do wysokiej godności”.

${ }^{63}$ Por. tamże: „,[Bóg] nie tylko nas przecież uwolnił od dawnego zła, lecz także przywiódł do anielskiego życia i otwarł przed nami drogę najlepszego postępowania, oddawszy nas pod opiekę sprawiedliwości, zgładziwszy dawne zło, spowodowawszy śmierć dawnego człowieka (por. Rz 6, 5-6) i zaprowadziwszy nas do nieśmiertelnego życia”.

${ }^{64}$ Tamże 11, 3, PG 60, 488, thum. Sinko, t. 1, s. 166.

${ }^{65}$ Tamże 10, 3, PG 60, 478, tłum. Sinko, t. 1, s. 154.

${ }^{66}$ Tamże 10, 2, PG 60, 477, tłum. Sinko, t. 1, s. 151. Chryzostom wiele razy wskazuje na 
Wspaniałomyślność i hojność, którą odznacza się Bóg, działa więc nieustannie jako zachęta do skruchy.

Zmiany sposobu życia należy się uczyć i wymaga ona nieustannych ćwiczeń i treningu, jednak przy odpowiednim wysiłku da się ją osiagnąć. Wyjaśniając tę kwestię Chryzostom odwołuje się do niezwykłych wyczynów akrobaty. Prosi słuchaczy, aby zastanowili się nad tym, jak trudno jest akrobacie swobodnie chodzić po linie, jak trudno jest mu rozebrać się i ubrać się podczas balansowania na linie. Czynności te są tak ryzykowne i przerażające, że strach ogarnia człowieka, gdy na nie patrzy. Zaś jeszcze niebezpieczniejsze jest trzymanie na twarzy tyczki, na której znajduje się dziecko. W tym kontekście Złotousty Kaznodzieja zapewnia słuchaczy, że zmiana sposobu życia, zdobycie cnoty i pójście do nieba jest o wiele łatwiejsze, jeśli tylko człowiek ma taką wolę ${ }^{67}$. Jeśli ktoś chce osiagnąć biegłość w jakimkolwiek rzemiośle ( $\left.\tau \dot{\varepsilon} \chi v \alpha i \varsigma\right)$, to nie wystarczy, że usilnie pragnie i życzy sobie tego, ale musi się faktycznie w tym ćwiczyć. „Jeśli ktoś chce zostać żeglarzem, nie mówi po prostu «Ja chcę», ale także bierze się za zadanie" 68 . Tak i życie moralne jest wyuczoną umiejętnością: „Uczmy się więc, aby później odnieść korzyść, uczmy się cierpieć niesprawiedliwie, gdyż to jest cechą chrześcijanina" ${ }^{69}$.

Chryzostom zauważa, że zdobytą cnotę łatwo można utracić. Zwracając się do mężczyzny, który udał się na przedstawienie do teatru, aby tam oglądać nagie kobiety, pyta: „Jakimi oczami popatrzysz po powrocie na swoją żonę?" ${ }^{70}$ Chryzostom był świadom uzależnień wynikających z chodzenia do teatru na niemoralne przedstawienia. $Z$ tego względu nieustannie kieruje apele do słuchaczy kazań, aby przerwali błędne koło ciągłego popadania w te same grzechy i powstrzymali się od zła, aby przyszli do Kościoła, gdzie po wyznaniu swych grzechów mogą otrzymać przebaczenie i doświadczyć Bożego

nadmiar hojności Boga. Na przykład, komentując tekst z Listu do Hebrajczyków $(9,21)$ o oczyszczającej mocy skropienia krwią ofiarną, mówi, że nie zostaliśmy po prostu skropieni oczyszczającą woda, ale wytrysnęła ona w naszych duszach jak fontanna (por. Joannes Chrysostomus, In epistulam ad Hebraeos hom. 16, 2, PG 63, 125).

${ }^{67}$ Por. tenże, In epistulam ad Hebraeos hom. 16, 4, PG 63, 127.

${ }^{68}$ Por. tamże, tłum. własne. Chryzostom mówi prawie to samo w homilii 8. na List do Hebrajczyków (PG 63, 74) o interpretacji Pisma: „Jeśli chcesz zostać żeglarzem lub cieślą, musisz się nauczyć podstaw sztuki ( $\tau \dot{\varepsilon} \chi v \eta)$. W przypadku Pisma ludzie tak nie postępują, chociaż jest to wiedza ( $\dot{\varepsilon} \pi \iota \tau \eta \dot{\mu} \mu)$, która wymaga głębokiej uwagi. Jest to także sztuka (rzemiosło) wymagające nauczenia", tłum. własne.

${ }^{69}$ Tamże 20, 3, PG 63, 146, tłum. własne.

${ }^{70}$ Tenże, De paenitentia hom. 6, 1, PG 49, 315, tłum. własne. Por. tenże, In Matthaeum hom. 6, 7, PG 57, 71, thum. J. Krystyniacki w: Św. Jan Chryzostom, Homilie na Ewangelię wedtug św. Mateusza, oprac. A. Baron, t. 1, ŹMT 18, Kraków 2000, 89: „Powiedz mi, jakimi oczami spojrzysz później na żonę w domu, skoro tam zobaczyłeś ją zhańbioną? Jak się nie zawstydzisz myśląc o swej domowniczce, skoro tam ujrzysz jej płeć znieważoną?”. Niektóre z najbardziej wyszukanych inwektyw Chryzostoma skierowane są pod adresem teatru. Swoich słuchaczy usilnie prosi, aby go unikali i przestali zatruwać swoją wyobraźnię; por. tenże, De paenitentia hom. 8, 1-2, PG 49, 338. 
miłosierdzia. Niestety - jak wynika z wypowiedzi Chryzostoma - nie było wielu tych, którzy chcieliby się nawrócić i szczerze wyznać grzechy. Dlatego Antiocheńczyk zauważa z ubolewaniem, że człowiek jest odważny gdy grzeszy, a zawstydzony, kiedy wyznaje grzechy, podczas gdy powinno być odwrotnie: człowiek powinien być śmiały w wyznawaniu grzechów, a zawstydzony, gdy popełnia grzech ${ }^{71}$.

Złotousty Kaznodzieja zauważa też, że grzech nie tylko niszczy życie duchowe konkretnej jednostki, ale jest także zaraźliwy. Może rozprzestrzeniać się przechodząc $\mathrm{z}$ jednej osoby na drugą. Zbezczeszczenie posagów rodziny cesarskiej było dla Chryzostoma dobrą okazją do wytłumaczenia tego problemu. Antiocheńczyk podkreśla, że chociaż mała grupa „obcych” wznieciła zamieszki z powodu ogłoszenia wyższych podatków ${ }^{72}$, to teraz całe miasto jest zagrożone. Podobną argumentację można dostrzec w 1. homilii O pokucie, gdy Chryzostom nawiązując do 1Kor 5, 1, twierdzi, że nawet ,zdrowi” Koryntianie byli winni zaistniałej sytuacji, ponieważ nie piętnowali, ani nie karcili grzesznika, który popełnił poważny grzech. Sądzili, że wina dotyczyła tylko jednego członka wspólnoty - tego, który zgrzeszył, podczas gdy ten, który zgrzeszył był przecież członkiem całego ciała - wspólnoty $^{73}$.

Chryzostom wkłada wiele wysiłku w zachęcanie swych wiernych, aby prowadzili życie prawdziwie chrześcijańskie. Nieustannie odwołuje się też do ich wymówki o tym, że są słabi i protestuje przeciw takiemu usprawiedliwianiu się. Przypomina wiernym, że przecież „mamy Boga, współpracującego [z nami] i pomagającego nam"74. Jedyne, co człowiek musi zrobić, to „przyłożyć się do sprawy jak do [prawdziwej] pracy"75. Ta prawdziwa praca, chociaż wymaga wysiłku, powinna być podjęta dobrowolnie. Dlatego Antiocheńczyk - nawiązując do perykopy biblijnej o bogatym młodzieńcu - przytacza i pokrótce analizuje słowa zachęty skierowane przez Chrystusa do zamożnego młodzieńca: „Jeśli chcesz być doskonały, idź, sprzedaj, co posiadasz, i rozdaj ubogim, a będziesz miał skarb w niebie" (Mt 19, 21). Chryzostom podkreśla, że Jezus nie wydał rozkazu, lecz powiedział ,jeśli chcesz”. To sformułowanie stało się inspiracją dla kaznodziei do skierowania zachęty, aby słuchacze zechcieli podjąć trud doskonalenia, gdyż to, co jest wykonywane z obowiązku lub nakazu nie przynosi wielkiej nagrody, jednak to, co się dobrego wykonuje z własnej woli, jest źródłem osiagnięcia szczególnej nagrody ${ }^{76}$. Innym razem Chryzostom twierdzi, że aby prowadzić życie chrześcijańskie, człowiek musi postrzegać świat inaczej.

${ }^{71}$ Tenże, De paenitentia hom. 8, 2, PG 49, 338-339.

${ }^{72}$ Prawdopodobnie chodzi o grupę zawodowych klakierów w teatrze, chociaż mówi się o nich jako o „obcych i cudzoziemcach”, „włóczęgach”, „łajdakach” i „ludziach mieszanej krwi”; por. tenże, Ad populum Antiochenum hom. 2, 3, PG 49, 38; tamże 3, 1, PG 49, 48).

${ }^{73}$ Por. tenże, De paenitentia hom. 1, 2, PG 49, 280.

${ }^{74}$ Tenże In epistulam ad Haebraeos hom. 16, 4, PG 63, 128, tłum. własne.

${ }^{75}$ Tamże, tłum. własne.

${ }^{76}$ Por. tenże, De paenitentia hom. 6, 3, PG 49, 318. Dokładnie taki sam argument pojawia 
To inne spojrzenie na świat przedstawia odnosząc się do zachowania dzieci. Mówi, że małe dziecko nie odczuwa strachu przed płonącą świeca, ale przeraża je maska teatralna. Podobnie człowiek żywi bezpodstawny strach przed śmiercią fizyczna, ale nie boi się grzechu, który jest śmiercią duchową. Z tego wynika, że strach przed grzechem jest bardziej uzasadniony ${ }^{77}$.

Przeszkodą w praktykowaniu życia prawdziwie chrześcijańskiego jest nieustannie krytykowana przez Chryzostoma - apatia. Z tego względu Złotousty Kaznodzieja ciągle zachęca wiernych do zaangażowania się w działalność społeczną, a szczególnie zaleca pomoc najbiedniejszym przez udzielanie jałmużny. Naucza przy tym, że jest to sposób ćwiczenia się w praktykowaniu żalu za grzechy ${ }^{78}$. Złotousty Kaznodzieja podkreśla, że nawet bardzo wzniosłe dziewictwo bez jałmużny nie ma wielkiego znaczenia ${ }^{79}$. Nawiązując do

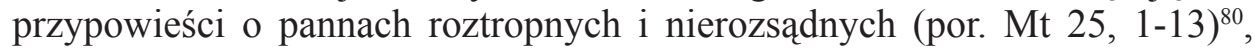
zaznacza, że dziewica, która nie udziela jałmużny zostanie odtrącona przez Oblubieńca $^{81}$. Tak więc wszelkie praktyki ascetyczne i modlitewne, gdy nie są poparte jałmużną, nie przynoszą duchowego owocu ${ }^{82}$. Udzielanie jałmużny wiąże się też z uwolnieniem się od zniewolenia bogactwem ${ }^{83}$. Chryzostom wielokrotnie wypowiada sie przeciw bogaczom i bogactwu. Wypowiedzi te są klasycznymi inwektywami ${ }^{84}$, a jednocześnie zachętami do praktykowania

się w innej homilii. Prorok Natan nie potępił Dawida od razu, ale pozwolił mu wyciągnąć własne wnioski z opowiadania; por. tamże 2, 2, PG 49, 286-287

${ }_{77}$ Por. tenże, Ad populum Antiochenum hom. 5, 3, PG 49, 73.

${ }^{78}$ Por. tenże, De paenitentia hom. 3, 1, PG 49, 292.

${ }^{79}$ Por. tenże, In illud: Vidua eligatur 15, PG 51, 336.

${ }^{80} \mathrm{~W}$ Chryzostomowej egzegezie przypowieści o pannach roztropnych i nierozsądnych, oliwa oznacza jałmużnę. Antiocheńczyk w egzegezie wspomnianej perykopy biblijnej stosuje nie tylko

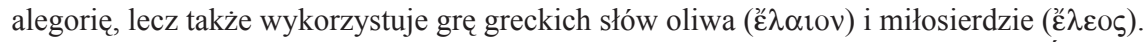

${ }^{81}$ Por. tenże, In Matthaeum hom. 77, 6, PG 58, 710, tłum. J. Krystyniacki w: Św. Jan Chryzostom, Homilie na Ewangelię wedlug św. Mateusza, oprac. A. Baron, t. 2, ŹMT 23, Kraków 2001, 414: „Choćbyś była czysta, choćbyś żyła w dziewictwie, bez udzielania jałmużny, zostaniesz za drzwiami oblubieńca (por. Mt 25, 1-13). A przecież cóż jest równe dziewictwu, które z powodu swej wzniosłości nawet w Nowym Testamencie nie zostało ustanowione jako nakaz prawa. Jednakże bez jałmużny zostaje ono odtrącone. Jeśli odtrąca się owe dziewice, jeśli nie mają/jałmużny/w należytej obfitości, to któż będzie mógł bez niej dostapić przebaczenia? Nie ma takiego, lecz kto jej nie ma, z pewnością będzie musiał zginąć".

${ }^{82}$ Por. tenże, In epistulam II ad Timotheum hom. 6, 3, PG 62, 633, tłum. T. Sinko, w: Św. Jan Złotousty, Homilie na Listy Pasterskie św. Pawła i na List do Filemona (Tym. I, II. Tyt. Filem.), przełożył i wstępem opatrzył T. Sinko, Kraków 1949, 252: „Pościsz każdego dnia? Lecz i owe dziewice wtedy pościły, a nic im z tego nie przyszło (por. Mt 25, 1-13). Modlisz się? I cóż z tego? Bez jałmużny modlitwa nie przynosi owoców; wszystko jest bez niej nieczyste, wszystko daremne; większa część cnoty zostaje zniszczona. «Kto nie miłuje brata swego», mówi Pismo, «nie zna Boga» (1 J 3, 11). A jakże ty miłujesz, kiedy nie chcesz się z nim podzielić nawet tymi małymi i lichymi rzeczami?"

${ }^{83}$ Por. tenże, De paenitentia hom. 3, 3, PG 49, 295-296.

${ }^{84}$ Przykładowo, w jednej z homilii na List do Rzymian, karci swoich wiernych za ozdabianie domów i zwierząt złotem oraz używanie kosztownych sprzętów, często wykonanych ze złota, srebra 
jałmużny. Warto jednak zauważyć, iż za oratorskim kunsztem stoją co najmniej dwa zagadnienia o fundamentalnej wadze. Po pierwsze, gorsząca nierówność w stanie posiadania uraga Chrystusowi. Chryzostom mówi:

„Pies jest u ciebie otoczony wielką troskliwością, zaś człowiek, a raczej Chrystus, z powodu psa i wymienionych zbytków, zostaje wtrącony w ostateczny głód. [...] Ten, który został stworzony na obraz Boga (por. Rdz 1, 27), stoi w haniebnych łachmanach z powodu twej nieludzkości. [...] Współuczestnik ciała Chrystusa, dla którego On z nieba zstąpił i przelał cenną krew, nie spożywa nawet nieodzownego pokarmu z powodu twojej chciwości" ${ }^{85}$.

Przytoczona wypowiedź Chryzostoma jest czymś więcej niż tylko ascetyczną awersją do bogactwa. Wkroczenie Syna Bożego w ludzkie życie uczyniło z chrześcijan braci i dało podstawy do postępowania bardziej etycznego. Drugą istotną kwestią poruszaną przez Antiocheńczyka jest uwypuklenie prawdy, że ludzie zamożni bardzo często poddają się zniewoleniu przez bogactwo. Jeśli nie mogą zdobyć się na rozdanie dóbr, to znaczy, że są oni przez nie posiadani $^{86}$ oraz że są winni bałwochwalstwa ${ }^{87}$ i dlatego powinni okazać skruchę i żal za grzechy.

W podsumowaniu warto zauważyć, że dla Chryzostoma życie chrześcijańskie jest wyborem egzystencji w komunii z Bogiem. Nie istnieje żadna chrześcijańska elita, gdyż każdy chrześcijanin - bez wyjątku - jest zaproszony do życia we wspólnocie z Bogiem, który pomaga człowiekowi w dążeniu do świętości. Bóg jest miłosierny i nigdy nie dąży do bezwzględnego rozliczania grzeszników z ich przewinień lecz obficie udziela przebaczenia pod warunkiem, że człowiek wstapi na drogę doskonalenia. Na tej drodze walki z grzechem i nabywania cnót człowiek nie jest pozostawiony samemu sobie, lecz zawsze wspierany jest przez Chrystusa, który w swej śmierci pogrzebał „starego człowieka" i nieustannie towarzyszy człowiekowi, aby unikając grzechu żył w świętości. Przestrzenią miłosiernej działalności Boga jest Kościół, który pełni rolę bezpiecznej przystani i portu oraz Arki nie tylko chroniącej, lecz także przemieniającej na lepsze wszelkie istoty przez ułatwienie walki z grzechem i umożliwienie duchowego rozwoju.

czy kości słoniowej; por. tenże, In epistulam ad Romanos hom. 11, 6, PG 60, 492. Na temat sytuacji zamożnych obywateli Antiochii zob. J.H.W.G. Liebeschuetz, The finances of Antioch in the fourth century A.D., ByZ 52 (1959) 344-356.

${ }^{85}$ Joannes Chrysostomus, In epistulam ad Romanos hom. 11, 6, PG 60, 492, thum. Sinko, t. 1, s. 171-172.

${ }^{86}$ Por. tenże, Ad populum Antiochenum hom. 2, 5, PG 49, 40.

${ }^{87}$ Por. tenże, In epistulam ad Hebraeos hom. 15, 4, PG 63, 121. 
FORGIVENESS OF SINS IN THE TEACHING OF JOHN CHRYSOSTOM. OUTLINE OF THE PROBLEM

\section{(Summary)}

This article attempts to show the teaching of John Chrysostom (c. 350-407) on the mercy of God and His love for mankind ( $\varphi \imath \lambda \alpha \nu \theta \rho \omega \pi i \alpha)$, which manifests itself in the forgiveness of sins. God loves all people, but sometimes allows them to suffer in order to bring them closer to Himself and show them His love (Chrysostom uses here the image of the father and the doctor). The loving closeness of God is an invitation for sinners to return to their loving Father. The Church is an area of activity of the merciful God. It is in the Church that the sinner can obtain forgiveness by practicing repentance. However, the return to the merciful Father cannot be limited to an act of will, but the decision of will must be followed by action - concrete attitude expressing a real desire to implement the decision.

Key words: John Chrysostom, Providence, sin, forgiveness of sins.

Słowa kluczowe: Jan Chryzostom, Opatrzność, grzech, przebaczenie grzechów.

\section{BIBLIOGRAFIA}

\section{Źródła}

Concilium Constantinopolitanum I (381), Expositio fidei CL patrum, ŹMT 24 [wydanie grecko-łacińsko-polskie, układ i oprac. A. Baron - H. Pietras], tłum. T. Wnętrzak, Kraków 2002 = DSP 1, 68-69.

JoAnnes Chrysostomus, Ad populum Antiochenum hom., PG 49, 15-222; ed. M.L. Cervini: Discorso esortatorio per l'inizio della santa quaresima, Corona Patrum Salesiana. Sanctorum Patrum Graecorum et Latinorum Opera Selecta. Series Graeca 16, Torino 1953; tłum. homilii 1. i 19. T. Sinko w: Św. Jan Złotousty, Dwadzieścia homilij i mów, Kraków 1947, 44-71 i 72-87.

JoAnnes Chrysostomus, De paenitentia hom., PG 49, 277-350.

JoAnnes Chrysostomus, In epistulam ad Hebraeos hom., PG 63, 9-236.

Joannes Chrysostomus, In epistulam ad Romanos hom., PG 60, 391-682, thum. T. Sinko:

Św. Jan Chryzostom, Homilie na List św. Pawła do Rzymian, oprac. A. Baron, t. 1-2, Kraków 1995.

JoAnnes Chrysostomus, In epistulam II ad Timotheum hom., PG 62, 599-662, tłum.

T. Sinko w: Św. Jan Złotousty, Homilie na Listy Pasterskie św. Pawła i na List do

Filemona (Tym. I, II. Tyt. Filem.), przełożył i wstępem opatrzył T. Sinko, Kraków 1949, 193-304.

JoAnnes Chrysostomus, In illud: Vidua eligatur, PG 51, 321-338.

JoAnnes Chrysostomus, In Matthaeum hom., PG 57-58, tłum. J. Krystyniacki (homilie

1-40, 61-90), A. Baron (homilie 41-60) w: Św. Jan Chryzostom, Homilie na Ewangelie

wedtug św. Mateusza, oprac. A. Baron, t. 1-2, ŹMT 18, 23, Kraków 2000-2001.

JoAnnes Chrysostomus, In paralyticum demissum per tectum, PG 51, 47-64. 


\section{Opracowania}

Browning R., The Riot of A.D. 387 in Antioch. The Role of the Theatrical Claques in the Later Empire, JRS 42 (1952) 13-20.

CiArlo D., Sulla teoria e la prassi della «providentia Dei» in Giovanni Crisostomo, „Atti della Accademia Pontaniana N.S." 56 (2007) 87-93.

Dragas G.D., St. John Chrysostom's doctrine of God's providence, „Ekklesiastikos Pharos" 57 (1957) 375-406.

FiLIPCZAK P., Bunty i niepokoje w miastach wczesnego Bizancjum (IV wiek n.e.), Łódź 2009.

French D.R., Rhetoric and the Rebellion of A.D. 387 in Antioch, „Historia” 47 (1998) 468-484.

LAMPe G.W.H., A Patristic Greek Lexicon, Oxford 1961.

LidDell H.G., ScotT R., Greek - English Lexicon, Oxford 1958.

Liebeschuetz J.H.W.G., Antioch. City and Imperial Administration in the Later Roman Empire, Oxford 1972.

Liebeschuetz J.H.W.G., The finances of Antioch in the fourth century A.D., ByZ 52 (1959) 344-356.

Paverd F. van de, St. John Chrysostom. The Homilies on the Statues, OCA 239, Roma 1991.

Stownik grecko-polski, red. Z. ABRAmowiczówna, I-IV, Warszawa 1958-1965.

Szczur P., John Chrysostom's Assessment of Drunkenness, VoxP 33 (2013) t. 59, 387-400.

Szczur P., Problematyka społeczna w późnoantycznej Antiochii na podstawie nauczania homiletycznego Jana Chryzostoma, Lublin 2008.

SzCzUR P., Rewolta podatkowa w Antiochii (387) w świetle przekazów Jana Chryzostoma i Libaniusza. Retoryka i fakty historyczne, „Roczniki Historii Kościoła” 1(56) (2009) 49-75.

Szczur P., Wady ludzi starych w ocenie Jana Chryzostoma, VoxP 31 (2011) t. 56, 371-382. 
